\title{
Land Swap Formula in the Nagorno-Karabakh Crisis Solution: Goble Plan and Lavrov Plan *
}

\section{Salih Yılmaz **}

\author{
Abstract \\ When we examine the history of Nagorno-Karabakh, we can see \\ that Armenian and Azerbaijani historians have been looking for \\ the truth in the thousand-year history which, in turn, creates \\ a controversial issue. The Nagorno-Karabakh Autonomous \\ Region was established in 1923 and had an official status within \\ Azerbaijan. In order to resolve this conflict, after the dissolution \\ of the USSR, solution proposals were presented under the \\ umbrella of the OSCE Minsk Group. In this study, plans based \\ on land swap and international solution proposals are discussed \\ comparatively. In addition, the land swap strategy that will be \\ implemented within the frame of the ceasefire agreement that \\ took place on November 9, 2020 and that will become a topic for \\ discussion in the future will be evaluated in this study.

\section{Keywords} \\ Nagorno-Karabakh, Minsk Group, Azerbaijan, Armenia, Goble \\ Plan, Lavrov Plan, Lisbon Declaration, Madrid Principles.
}

"Date of Arrival: 21 December 2020 - Date of Acceptance: 30 November 2021

You can refer to this article as follows:

Yllmaz, Salih. "Land Swap Formula in the Nagorno-Karabakh Crisis Solution: Goble Plan and Lavrov Plan." bilig, no. 100, 2022, pp. 177-209.

" Prof. Dr., Ankara Yildirim Beyazit University, Faculty of Humanities and Social Sciences, Department of History - Ankara / Turkey

ORCID: 0000-0002-5413-0703

salihyilmaz76@gmail.com 


\section{Introduction}

In history, Armenians gained power in Caucasia and Anatolia with the Treaties of 1813 Gülistan, 1828 Türkmençay and 1829 Edirne. They have gained land in the Caucasus with the influence of Russia (Tohidi 2). After the Treaty of Turkmencay, many Armenians were settled in NagornoKarabakh and present-day Armenia through immigration (Taşkıran 75) In Russia's policy of settling Armenians through immigration, the aim of creating a buffer zone against the Turks in the region and securing their own borders has been a priority (Mehmediyev 90). Since 1828, Armenians were settled in Karabakh, Yerevan and Nakhchivan and caused the demographic structure of the region to change.

In 1914 World War I, when the Ottoman Empire became Russia's rival, Russia started to use Armenians more and settle them in the region. In the Caucasian front, Armenians were used in the war against the Turks (Özkul 244). With the October Revolution that took place in Russia on November 11, 1917, a new era began in the Caucasus. Armenians made an effort to establish their own state (Özçelik 81). Armenians, except Tashnak Armenians, supported the Bolshevik Revolution in order to get the support of the Russians and made an effort to drive the Azerbaijani Turks out of their soil (Özkul 244-245). With the 1917 Revolution, the 11th Red Army from Russia invaded the Republic of Azerbaijan. With the support of Russia, Karabakh was declared an autonomous region in 1923. Karabakh is divided into 2 parts: mountainous (upper) and plain (lower). Armenians were forced to migrate to the mountainous part called upper and an artificial state was created (Aras vd. 28-29, Neciyev 163-186).

In the Nagorno-Karabakh region, which is an autonomous region affiliated to Azerbaijan, since the 1960s, the efforts of Armenians to oppose autonomy and to connect the region to Armenia have resumed (Sarıhmetoğlu 13). Between 1980-1994, Armenians frequently rebelled for the independence of the Karabakh region or its attachment to Armenia (Mustafayev 2015: 214). During this period, civilian Azerbaijanis were targeted and provocations were made with the aim of Russia's intervention in the region (Mehmedova 90-91). 
The Nagorno-Karabakh problem arose during the USSR Period in 1988, when Armenians declared their independence; they wanted to attach Nagorno-Karabakh region to their lands in Armenia (Cheterian 93-94). Depending on the conditions of the period, the USSR administration acted in favor of the Armenians, allowing a crisis area in the region (Şavrov 59 61).

The beginning of the "Karabakh conflict" between Armenia and Azerbaijan generally dates back to February 1988. However, the beginning of the first problems, which are barely remembered even by residents, occurred in Armenia and Azerbaijan, not in Karabakh (Vahapzade 173). In the mid1980s, it was estimated that around 350.000 Armenians lived in Azerbaijan (excluding the residents of Nagorno-Karabakh) and 200.000 Azerbaijanis lived in Armenia. In the autumn of 1987, ethnic tensions in both republics intensified noticeably, as if both peoples suddenly grasped a kind of signal to initiate an action. In October 1987, a conflict broke out between local authorities and Armenian residents in the village of Çardaklu, in northern Azerbaijan. Armenians rejected the appointment of an Azerbaijani as director for a state farm. Armenians paid special attention to Çardaklu since this was the birthplace of two Armenian marshals of the Soviet Union, Ivan Baghramyan and Hamazasp Babajanyan. On October 18, a small group of protesters was gathered in Yerevan regarding the events in Çardaklu. Soon, some struggles broke out in the south of Armenia, in the regions of Meghri and Kafan, where Azerbaijanis densely populated in many villages (De Waal 20-21, Musayev 11).

The forced expulsion of about 200.000 Azerbaijanis from Armenia in 1988-1989 was not sufficiently covered neither in the Soviet press nor in the international press. It was not known by many that around 50.000 Azerbaijanis were deported from Armenia in the 1940s. Prior to this, thousands of Azerbaijanis were killed in clashes in 1918-1920 (Vsesoyuznaya 11-13, Imranli-Lowe 219-236). In 1998, President Aliyev declared 31 March as the Day of Genocide of the Azerbaijani People, in memory of those killed during all these events. This date was chosen since the massacre of Muslims began in Baku on March 31, 1918.

While trying to identify the roots of the Karabakh problem, we must first reject the idea that this is an "eternal conflict". The Armenia-Azerbaijan conflicts, 
both in form and content, arose more than a hundred years ago. NagornoKarabakh, which became the cause of rivalry in 1905 and 1918-1920, was annexed to Azerbaijan in 1921 and its present borders were determined in 1923 (İsmayl 86, Swietochowski 8). The Executive Committee of the USSR, encouraged by determining the borders of Karabakh, changed the borders of Nakhchivan without the consent of Turkey, which is the guarantor of Nakhchivan's status, with February 18, 1929 dated decree, and 9 villages of Nakhchivan, Gorçevan village and part of Kilid village of Ordubad district were given to Armenian SSR (Mehmetov 647-648, Azərbaycan Tarixi 357, İbrahimova vd. 28-84, Şıhaliyev 175-192). All this means that the conditions of the Moscow and Kars Treaties regarding the status and borders of the Nakhchivan SSR have been violated. The return of these villages to Nakhchivan by bringing the Moscow-Kars Treaties to the agenda in the final peace negotiations between Azerbaijan and Armenia is a right according to international law (Lütem 237). During the dissolution of the USSR in the 1990s, Karabakh declared its independence on September 2, 1991. However, the declaration of independence was not accepted by any state.

With the declaration of the independence of Azerbaijan on August 30, 1991, the Armenians declared the Artsak Armenian Republic (Özçelik 97). In mutual military competition, on September 24, 1991, as a result of the Jeleznevodsk negotiations, a ceasefire agreement was signed. Armenia has accepted that Karabakh is bound to Azerbaijan. However, Armenians who took advantage of the political conflicts in Azerbaijan and wanted to use the role of Russia in the Chechen crisis, attacked the Khojaly village in February 1992 and committed a massacre (Özçelik 98-99, Aktaş 50). After these attacks, Organization for Security and Cooperation in Europe (OSCE) decided to convene in Minsk on 24 March 1992. In 1993, meetings were held by Minsk group representatives on the solution of the problem.

In this article, it is a priority to put forward the land swap that is expected to come into the agenda in the final agreement in the resolution of the NagornoKarabakh crisis and to put forward the solution proposals regarding this in the past, and to draw attention to the political and economic implications of the land swap between Azerbaijan and Armenia in the future agreement. It is necessary to contribute to the reconciliation of the parties in the final 
agreement by examining the reasons for the deadlock in the previous negotiations by determining the transition period set forth by the ceasefire agreement signed on 9 November 2020.

It can be argued that the causes of the current Nagorno-Karabakh conflict are hidden in the rivalry fields of the twentieth century. At the beginning of the $21^{\text {st }}$ century, Azerbaijan's foreign policy developed in two directions. First, it developed with neighboring countries (Georgia, Turkey, Russia and Iran) and co-operation; secondly, it had a mutual and close relationship with Western and NATO countries (Mehdiyev 234, Kouhi-Esfahani 96). In Armenia, when Pashinyan came to power in 2018, relations with the United States began to develop while trying to reduce dependence on Russia. According to Russia, the US controlled its Caucasus policies through Armenia. There was a crisis of trust between Moscow and the Pashinyan administration. It is known that Russia took note of Pashinyan's antiMoscow policies. Just two days before the clashes broke out on September 25,2020 , the country's leading opposition party leader Gagik Tsarukyan (also known for his pro-Russian line) was arrested in Armenia. A short time ago, Pashinyan's ministers brought up the issue of closing the Russian base in Gyumri. Pashinyan, who came to power in Armenia, underestimated Russia for a long time. "When Putin asked for something" Yerevan ignored it. Yerevan followed a policy towards rapprochement with the West and separation from Russia (Yılmaz, Rusyánın Dă̆lık Karabă̆). Some Russian experts list Russia’s main expectations from Armenia as follows:

- Pashinyan did not officially recognize Crimea as Russian on behalf of Armenia despite Russia's request, which was seen as hostility by Russia.

- Armenia started to cooperate with NATO in many fields during the Pashinyan period. Russia, on the other hand, was disturbed by all kinds of cooperation of Armenia with NATO.

- NGOs financed by Soros and the USA were effective in Pashinyan's rise to power. Although Russia expressed its discomfort with the activities of these NGOs to Armenia many times, their demands were left unanswered.

- Many pro-Russian politicians and businessmen were arrested in Armenia during the Pashinyan period. Russia’s demands to end the persecution of pro-Russian politicians were ignored. 
- With the Pashinyan administration, the number of employees of the US Embassy in Yerevan increased significantly. According to Russia, about 2.000 US people started work in Yerevan.

- Russias influence in Armenia was weakened with the Pashinyan administration. Russian TV channels were banned.

- The Pashinyan administration made an investigation against GAZPROM and tried to establish a negative image for Russian companies. Russia, on the other hand, saw this as a conspiracy by the USA against itself.

- Some ministers in the Pashinyan government made statements regarding the closure of the Russian military base in the country. Russia, on the other hand, thought this was a strategy Pashinyan would implement in the future ((Yılmaz, Rusya'nın Dă̆glk Karabă̆).

The different policies implemented by Azerbaijan and Armenia caused Armenia to become isolated from other countries in the region. We can say that Pashinyan's strategy, which he expected from the West to win a victory, failed. In Azerbaijan, the result is determined on the battlefield. Prigozhin, who is a founder of Russian mercenary company WAGNER and close to the Kremlin, summarized Russia's discomfort with Armenia in an interview with the journalists of the press service of IA REGNUM and Concord: Karabakh is Azerbaijani territory, while Pashinyan is the US puppet (RİAFAN, Пригожин считает).

The war that started between Azerbaijan and Armenia on September 27, 2020 lasted 44 days and ended with a peace agreement on November 9, 2020 for now. The terms of the peace agreement are as follows:

1. A complete ceasefire and end to all hostilities in the Nagorno-Karabakh conflict is hereby declared from 00:00 Moscow time on 10 November 2020. The Republic of Azerbaijan and the Republic of Armenia, hereinafter referred to as the Parties, shall stay at the positions they occupy.

2. The Agdam District shall be returned to the Republic of Azerbaijan by 20 November 2020.

3. Along the line of contact in Nagorno-Karabakh and along the Lachin corridor, a 1,960-strong peacekeeping contingent of the Russian 
Federation with small arms, 90 armoured personnel carriers, and 380 vehicles and other pieces of special equipment shall be deployed.

4. The peacekeeping contingent of the Russian Federation shall be deployed in parallel with the withdrawal of the Armenian armed forces from Nagorno-Karabakh. The duration of the peacekeeping contingent of the Russian Federation is 5 years and it is automatically extended for another 5 years unless one of the Parties should serve a 6 months' notice to contrary.

5. For the purpose of improving the effectiveness of enforcing the agreement by the Parties to the conflict, a peacekeeping centre in charge of enforcing the ceasefire shall be deployed.

6. The Republic of Armenia shall return the Kalbajar District to Azerbaijan by 15 of November 2020, and the Lachin District by 1 December. The Lachin corridor ( $5 \mathrm{~km}$ wide), which will provide access from Nagorno-Karabakh to Armenia and bypass the town of Shusha, shall remain under the control of the peacekeeping contingent of the Russian Federation. Subject to agreement by the Parties, a construction plan will be determined in the next three years for a new route of movement along the Lachin corridor, providing a link between Nagorno-Karabakh and Armenia and then the Russian peacekeeping contingent shall be deployed to protect this route. The Republic of Azerbaijan shall guarantee the safety of traffic of citizens, vehicles, and goods along the Lachin corridor in both directions.

7. Internally displaced persons and refugees shall return to the territories of Nagorno-Karabakh and adjacent areas under the control of the UN Office of the High Commissioner for Refugees.

8. The exchange of prisoners of war, hostages and other detainees as well as the remains of the fatalities shall be carried out.

9. All economic and transport links in the region shall be unblocked. The Republic of Armenia shall guarantee the safety of transport links between western regions of the Republic of Azerbaijan and the Nakhchivan Autonomous Republic with a view to organizing the unimpeded movement of citizens, vehicles and cargo in both directions. The control over the transport communication will be exercised by 
the Border Service of the FSB of Russia. Subject to agreement by the Parties, the construction of new infrastructure linking the Nakhchivan Autonomous Republic with regions of Azerbaijan shall be carried out (Yılmaz, Ermenistan-Azerbaycan Barış Anlaşmasının 34).

When we evaluate the articles of the ceasefire agreement between Russia, Azerbaijan and Armenia, we can say that the following views come to the fore:

- There is no explanation within the articles of the agreement about the administration of Nagorno-Karabakh and about ensuring internal security. For example, will Azerbaijan be able to appoint its own governor or a police chief here? Will it serve as the Russian Peacekeeping Force or will it also function as a police force? If it will also serve as a police force, it means that all internal and external security is handled over to Russia. In other words, the control of your own land is passed to Russia for 5 years. Although it is said that Nagorno-Karabakh does not have a status, an open door was left in the final peace agreement to negotiate this situation. It can be explained that unrecognized state of NagornoKarabakh announced Russian language as its official language in order to strategically get Russian support in terms of its status in the future.

- Article 7 of the agreement states that "Internally displaced persons and refugees shall return to the territories of Nagorno-Karabakh and adjacent areas under the control of the UN Office of the High Commissioner for Refugees.", which means that the displaced people will regain their homes and lands in exchange for proof that their property belongs to them. However, only the Azerbaijanis who immigrated from Zangezur Region in 1988 with the expression of Nagorno-Karabakh were not taken into account. If the return of the Armenians was guaranteed, the return of the Azerbaijanis to their villages in Zangezur should also be guaranteed. With this article, all the assets of the Armenians were guaranteed. In other words, Armenians will be able to return to the regions under the control of Azerbaijan as they wish.

- Article 9 of the agreement states that; "All economic and transport links in the region shall be unblocked. The Republic of Armenia shall guarantee the safety of transport links between western regions of the 
Republic of Azerbaijan and the Nakhchivan Autonomous Republic with a view to organizing the unimpeded movement of citizens, vehicles and cargo in both directions. The control over the transport communication will be exercised by the Border Service of the FSB of Russia. Subject to agreement by the Parties, the construction of new infrastructure linking the Nakhchivan Autonomous Republic with regions of Azerbaijan shall be carried out." With this article, just as the Lachin corridor, it was decided to open a transport corridor between Azerbaijan and Nakhchivan. However, there are no explanatory conditions regarding the Nakhchivan corridor, although the length of time (3 years) and width $(5 \mathrm{~km})$ of the Lachin Corridor are specified. For example, when will this corridor be constructed? How long will it be? Where will it pass through? There is no clear article regarding this. In the text of the agreement, the expression of "movement of citizens, vehicles and cargo" was used for the Nakhchivan corridor while the Russians announced that it was only for people and food passage. If these corridors cannot be used for trade, then it cannot go beyond just an excuse for Russia to stay in the region. Again, the main drawback in the article is that it is not specified for how many years the Russian FSB Border Guards will control the transportation. As it stands, will the Russians control the Nakhchivan corridor indefinitely? The duration of this should have been certain. A 5-years-period is specified for Lachin corridor, but no time is specified for Nakhchivan corridor. The corridor is made dysfunctional by giving Russia an indefinite control. This article must be updated. Turkey must be the guarantor of Nakhchivan corridor (Yilmaz, Ermenistan-Azerbaycan 34-37). After the ceasefire agreement, Russia increased its military effectiveness in the border regions of Armenia and established new police stations. In this context, Turkey's setting up of military bases on the borders between Azerbaijan-Armenia, depending on the military cooperation agreement with Azerbaijan, will be a deterrent for conflict prevention in the future.

As a result, the agreement is profitable for both Armenia and Azerbaijan as it contributes to the solution of the problem. Azerbaijan has taken its main occupied lands as it had previously wanted. Armenians, on the other hand, reached a situation in which their properties were guaranteed and they could live freely in the regions where they densely lived in 1988. The only 
loss for Armenians is that their opportunity to gain independence has been lost. It is not possible to find a solution unless it agrees with Turkey and Azerbaijan. The benefit for Azerbaijan is that it provides territorial integrity with the Nakhchivan corridor. Russia establishes a security wall in UkraineDonbas, Crimea, Moldova-Transnistria, Georgia-North Ossetia-Abkhazia, Azerbaijan-Nagorno-Karabakh, Iraq-Northern Iraq and Syria (Yllmaz, Putin Era 442). Within this wall, only Northern Iraq is seen as the place that cannot be fully active for now. The effect attempted to be established over Rosneft in Northern Iraq is faced with the objection of England. Russia is trying to strengthen its influence in this region through Iran.

We should say that the "Peace Agreement" between Armenia and Azerbaijan has not yet reached a final result on Karabakh and many other issues. If this ceasefire agreement is not finalized before the end of 5 years and a definitive agreement with international validity is not signed, a crisis is likely to occur in the region. For this reason, we can say that it will be useful to evaluate the land swap formula that will come to the agenda in the final agreement.

The First Nagorno-Karabakh War took place between Azerbaijan and Armenia between February 1988 and May 1994. Although the Karabakh crisis started in 1988-1989, when the Armenians held a referendum for independence and decided on independence, it resulted in the occupation of 7 regions belonging to Azerbaijan and a ceasefire was established through mediators. Negotiations were held on 4-5 May 1994, on the initiative of the Inter-Parliamentary Assembly of the Member Nations of the Commonwealth of Independent States, the Russian Federal Assembly and the Ministry of Foreign Affairs, and hosted by the Council of the Kyrgyz Republic. On May 4-5, 1994, the Bishkek Protocol was signed by the Presidents of the Parliament of Azerbaijan and Armenia, who came together in Bishkek with the mediation of Russia (De Waal 251, Abdullayev 104). The ceasefire entered into force on May 12, 1994. The aim was first to stop the war and then to resolve the problem peacefully. The difference of this agreement from other ceasefire agreements is that it is realized without any foreign military power being placed in the war zone (Kerimov 127). Following the ceasefire agreement, proposals for final peace were made under the leadership of the UN OSCE Group on the resolution of the problem. Although land swap was tried to be brought to the agenda in both peace proposals, the problem 
was not resolved due to the objection of Armenia. These two declarations deepened the problem rather than focusing on the solution.

\section{Lisbon Declaration}

After 1988, there are four main plans and two main agreements regarding the solution of the crisis in Karabakh. The main agreements are the Lisbon Declaration and the Madrid Principles. On 2-4 December 1996, 54 participating states recognized the territorial integrity of Azerbaijan with the meeting of the heads of states and governments of OSCE member countries in Lisbon, the capital of Portugal. Armenia did not sign the Lisbon Declaration (Hasanov 96). The decisions taken at this summit are summarized as follows:

- Territorial integrity of the Republic of Azerbaijan and the Republic of Armenia;

- Granting the highest autonomy status to Nagorno-Karabakh within the borders of Azerbaijan;

- Ensuring the security of the entire population of Nagorno-Karabakh.

After the Lisbon Summit, a co-chair from France, Russia and the USA was appointed to the OSCE Minsk Group in January 1997. Although this cochair had made 3 offers to Azerbaijan and Armenia, one was not accepted by Azerbaijan and the other two by Armenia. The plans offered by the Minsk Group are as "Package Solution, "Phased Solution" and "Common State". In these three plans, it was stated that the armed forces of Armenia should leave Azerbaijani lands. The first plan "Package Solution" was presented on 17 July 1997. In this plan, two treaties were signed; one for determining the conditions of peace and the other was for determining the status of NagornoKarabakh. Nagorno-Karabakh was given a special status within Azerbaijan (İşyar 577-595, Ziyadov 109, Mehtiyev 126). Phased Approach plan was presented on December 2, 1997. In this plan, firstly, it was proposed to ensure full peace, then to determine the conditions for the return of refugees and the status of Karabakh, and ultimately to return Lachin, Shusha and former Shaumyan provinces to Azerbaijan. The "Common State" plan was presented on 7 November 1998 (Azerbaycan Gazetesi, Hesenov 88). According to this plan, the establishment of an independent NagornoKarabakh Republic and a joint state model with Azerbaijan were proposed. 
The first two drafts were rejected by Armenia and the third by Azerbaijan (Kerimov 32, Hesenov 122).

\section{Madrid Principles}

Madrid Principles were formulated in 2007 to solve the Nagorno-Karabakh crisis between Azerbaijan and Armenia. The plan, which highlights three conditions (non-conflict, territorial integrity and self-determination), was first adopted by both countries. According to the Madrid Principles, firstly, it was proposed that Armenia should withdraw its troops from the regions occupied. Secondly, the withdrawal of the Armenian troops in Lachin and Kalbajar, the return of Azerbaijani immigrants, and giving a wide autonomy to Karabakh were proposed. Recommendations were made on holding a referendum in Nagorno-Karabakh (OSCE Minsk Group 2007, Ziyadov 120, Pokalova 77). Until the last tension in early April 2016, the "Madrid Principles" continued to be presented in a renewed manner. The basic 6 principles are as follows:

- The return of the territories surrounding Nagorno-Karabakh to Azerbaijani control.

- Giving an interim status for Nagorno-Karabakh and providing guarantees for security and self-governance.

- The right of all internally displaced persons and refugees to return to their former places of residence.

- A corridor linking Armenia to Nagorno-Karabakh.

- Eventual determination of the final legal status of Nagorno-Karabakh through a legally binding expression of will.

- International security guarantees, including a peacekeeping operation (Madrid Ministerial Council Document, OSCE Minsk Group Press Release 2008, Ziyadov 120).

While Madrid Principles were being discussed, the ceasefire was partially broken in 2016 and talks were suspended (Nagorno-Karabakh 3). In the process that began in 2016 after the Arab Spring, Russia-Turkey reproached and the talks between the two countries for resolving the Nagorno-Karabakh crisis has brought to the table several times in the meetings in Sochi (Yilmaz 
2019b). Turkey-Russia negotiations were shaped in the framework of the decisions taken by the UN (Akçay 101-129, Makili-Aliyev 76-82). There are more than one UN resolutions demanding the liberation of Azerbaijan's occupied territories. The UN Security Council issued a resolution in 1993, confirming that Karabakh is a part of Azerbaijan. The Council of Europe took the same decision in 2005 (Leckie 44-53). In 2008, the United Nations General Assembly called on Armenia to immediately leave the Azerbaijani territories it occupied (Baguiyov 11-24). A new proposal emerged in Turkey-Russia Talks in the framework of mainly Goble Plan (1992), which was brought to the table, and the Lisbon Declaration and the Madrid Principles. This proposal was also called the Lavrov Plan or the Moscow Principles, which was prepared after the 4-days war in 2016. The cooperation between Russia and Turkey in Syria and Libya has influenced the solution of the Nagorno-Karabakh conflict. This cooperation caused Russia to put pressure on Armenia for a solution in Nagorno-Karabakh. Because Russia has concerns that a crisis that may arise with Turkey can negatively affect the cooperation in Syria and Libya, it made the suggestions about the solutions Nagorno-Karabakh be accepted.

\section{Solution Proposal in Karabakh: Goble Plan and Assassination in Armenia}

The land swap for the settlement to Karabakh conflict between Azerbaijan and Armenia was on the agenda in talks between Turkey and the US for the first time. Turkey supported Azerbaijan unconditionally during Turgut Ozal era and even mutual statement was given with Russia on this issue (Abilov 33). Land swap was brought to the agenda to find a solution to the Karabakh crisis during Turgut Ozal's visit to the USA. In the Ozal-Bush meeting in the Oval Office on April 28, 1992, the plan for a land swap between Azerbaijan and Armenia was discussed. This plan had a doublecorridor formula and these corridors included Lachin and Meghri. The Karabakh-Meghri swap was proposed as a solution. This "Corridor Change Plan”, which was suggested by Turgut Ozal in 1992, was brought back as a solution by Paul Goble, an expert on Eurasia issues at the US Ministry of Foreign Affairs. The text known as the Goble Plan was actually based on land swap as Turgut Ozal mentioned (ANI 2019, RUSEN 2020). In 
October 1992, UN representative Maresca also offered a land swap. It was suggested that Zengezur should be given instead of Lachin.

The Goble Plan takes its name from the American diplomat who proposed it in 1994. This is a plan based on the land swap between Armenia and Azerbaijan for the final solution of the Karabakh conflict. The Goble Plan is the return of Armenians to most of Azerbaijan's occupied territories and the exchange of part of the Meghri region in southern Armenia (adjacent to Iran) in exchange for the so-called Lachin corridor (Azerbaijan's Lachin region). One of the variants of this plan is to give Armenia a "corridor" from Yerevan to the Iranian border on the west of Nakhichevan to compensate for the loss of access to Iran. Thus, it will be possible for Azerbaijan to interconnect its borders and to have direct access to Turkey border, and it will provide communication between Armenia and Iran (Jacoby 32). However, many Armenian politicians, has brought the geopolitical risk of the emergence of "Great Turkey" and the risk of losing the corridor leading to Iran to the agenda. The main concern of the discussion is that Armenia is entirely surrounded (Georgia, a common border, is not a reliable friend for Yerevan), it is allowed to grant direct access to Azerbaijan's regions and connecting the border with Turkey (De Waal 263).

The "Common State" solution, a proposal that survived for only five months between March-December 1998 and abandoned by the Minsk Group after Azerbaijan was rejected, was also proposed for Azerbaijan, Georgia and Moldova. In this plan, the separatist units within Azerbaijan, Georgia (Abkhazia) and Moldova would unite in the "single state" model. Accordingly, Karabakh and Azerbaijan would form a common state. The proposal also gave the right to establish foreign representation in Karabakh. Azerbaijan was planned to become a confederation (Kilavuz 57-58, Laitin and Suny 168).

Goble Plan was rejected by many representatives of the Azerbaijani administration in 1999. In October 1999, three closest advisors to Heydar Aliyev resigned due to disagreements on the matter. They resigned because there was a possibility of accepting the Goble plan by their government. These were long-term foreign policy advisor Vafa Guluzade, head of the presidential administration Eldar Namazov and foreign minister Tofik Zulfugarov. 
In Armenia, the Goble Plan provoked more controversy; for Armenia, the loss of Meghri meant the loss of its southern border with its friendliest neighbor, Iran. In fact, Iran was also against this plan. For Kocharian, who was born in Karabakh, the accusation that he sold the territory of the Republic of Armenia to secure the future of Nagorno-Karabakh was a concern (Laitin and Suny 167). Hence, Kocharian needed the support of Defense Minister Vazgen Sargsyan, who became Armenia’s most influential politician in the summer of 1999 , hoping to implement this plan. Kocharian traveled to the United States. At the same time, he received a warning from the Armenian Diaspora, which was against the plan. Diaspora claimed that they would not support the country both financially and militarily. The impact of the Armenian Diaspora in the Nagorno-Karabakh crisis has been increasingly decisive after 1990 (Ismailzade 7, Başer and Swain 45-62). On October 11, Aliyev and Kocharyan held a two-hour meeting at the border between Nakhchivan and Armenia. This was their fifth meeting in the past six months. At the OSCE summit in Istanbul in November, there was hope that both sides would declare at least one framework agreement on Nagorno-Karabakh.

On October 27, 1999, US Deputy Secretary of State Strobe Talbott visited Yerevan on his way to Istanbul. He held talks with Kocharian and Vazgen Sargsyan before going to the airport. Then Sargsyan went to the Armenian parliament to attend the meeting in which the government answered the questions of the deputies. This parliamentary meeting was raided by armed Armenians of Tashnak volunteers. Eight people, including Prime Minister Sargsyan and Parliament Speaker Demirchyan, died and eight were injured in this raid (Mufson 1999). These murders caused some political crises in Armenia and drove the country away from its main political line. According to one version, the attackers were ordered to support the peace plan and prevent an imminent action in the Nagorno-Karabakh negotiations by eliminating Sarkisyan, who was ready to make a land swap. The timing of the assassination right after Sarkisian's meeting with Strobe Talbott was a planned action. Talbott later told the media that both sides were "very, very close" to reach an agreement and that the massacre was a "humanitarian, political and geopolitical disaster" (Baker and Danielyen 1999, Asbarez 1999). Finally, Sargsyan was a close ally of Russia in power structures that could be fully involved in disrupting the peace plan initiated by the 
United States. Despite this, it has always been spoken in Armenia that this assassination was planned by the Russian secret services, which were not satisfied with the peace plan and land swap.

While the peace plan and land swap were on the agenda in Armenia's domestic politics in 1999, the peace process was temporarily suspended after the attack. Kocharyan had to struggle with the Yerkrapah movement, which demanded the dismissing of the responsible people after Vazgen Sargsyan's assassination. It took more than a year for Kocharyan to regain his power (Kelbizadeh 73-94). The dialogue between Aliyev and Kocharyan literally resumed at the end of 2000. Until then, the idea of a large-scale land change was no longer on the agenda, as it was not supported in Azerbaijan (How the "Goble Plan" was born 2000). The parties started talking about the land swap plan in 1999. The land swap plan, also known as the Goble Plan, dedicated to the US State Department's regional expert Paul Goble, was planned to sign the peace agreement at the OSCE summit to be held in Istanbul in November 1999, as a result of the negotiations between the presidents of both countries (Ziyadov 117). If there had been no assassination in Armenia, it was predicted that both sides would have been very close to signing such an agreement. The negotiations on swap plan took long time and there were hesitations on this issue since there was no agreement on where the corridors would pass and how deep they would be (Ambrosio 99). Negotiations stopped for a while after the attack in the Armenian parliament. Kocharyan withdrew from a solution in the negotiations due to the security weakness in Armenia (Huseynov 17, Kılavuz 59).

The Goble Plan, which was interrupted by the assassination in Armenia, was re-discussed at a meeting held in Key West/Florida in 2001. It was thought that this proposal would completely solve the problem between the two countries; because Armenians in Karabakh would get the security guarantee while Azerbaijan would preserve its territorial integrity. However, the proposal could not be brought to the signature stage (Harutunian 72 , Armenia and Azerbaijan 2001, İsmayllov 121). After the peace plan was destroyed by an assassination, the power in Russia also changed. Russia's new president, Vladimir Putin, began to pursue a more coordinated policy in the Caucasus. Putin, who started a new war in Chechnya and had a harsher attitude against Georgia, began to develop relations with Azerbaijan. On 
an official visit to Baku in January 2001, Putin supported Heydar Aliyev. In 1949, he awarded Aliyev with a graduation diploma from the Leningrad KGB Academy. This was the first public confirmation that Aliyev was studying in Leningrad.

On the resolution of the Karabakh crisis in 2001, the three countries France, Russia and the United States, which served as co-chairs of the Minsk Group, seemed to be working closely together for the first time. Peace process progressed (Hopmann 10-11, Lütem 9-39). Aliyev and Kocharyan held two successful meetings in Paris under the presidency of French President Jacques Chirac (Mehtiyev 2). However, "leaks" were published simultaneously in Armenian and Azerbaijani newspapers, as if it had been decided in advance. The texts of the three peace plans prepared by the Minsk Group in 1997 and 1998 were leaked by someone. It can be said that these "leaks" were made to test public opinion on Karabakh and to lay the groundwork for a fourth plan, completely different from the first three. The public reaction to the first three plans was very hostile, especially in Azerbaijan. Almost nobody in Baku supported the reconciliation.

It was reflected in the press that Aliyev made important concessions on the most sensitive issue, namely the status of Nagorno-Karabakh. An official who attended the talks basically stated that he considered NagornoKarabakh as "an inseparable part of Armenia". This surprising proposal to renounce all that is sacred to many Azerbaijanis was followed by a series of Armenian mutual concessions, including the right for Azerbaijani refugees to return. Heydar Aliyev agreed to take Meghri from Armenia in exchange for Nagorno-Karabakh.

Why did the President of Azerbaijan make this unexpected move? As one Western diplomat explained, Aliyev adhered to the "all or nothing" principle. He wanted to take Karabakh completely or to leave it completely. The last thing the Azerbaijani president could accept was that there was an uneasy Armenian-populated region nearby. Aliyev wanted to solve the problem by land swap, which was thought to be the best solution. However, Aliyev's plan was not supported by the Azerbaijani political elite. Ultimately, the peace initiative could not be explained because of the dissidents who broadcast to the public about the complete establishment of Azerbaijan's control over Karabakh. The differences between what Aliyev said privately 
and his public statements caused some reactions. Negotiations resumed in April 2004 after Ilham Aliyev became the president. Several meetings were held between Azerbaijan and Armenia in Prague between 2004 and 2005, and they are known as the "Prague Process" (Mehtiyev 3, Coyle 115-164, Özkök 2004, Caferov and Aslanlı 252).

\section{Lavrov Plan and 2020 Ceasefire Agreement}

As explained before, after the Paris negotiations, land swap was also on the agenda in the Vienna talks in 2002, but no agreement could be reached. Negotiations for peace between the two countries were held in Prague in 2004, but they did not yield positive results. A roadmap for peace was drawn in the 2007 Madrid Principles. In 2008 this roadmap was updated to Madrid principles. The previous plans were mentioned in the 2008 Moscow Declaration. However, all the plans that came to the agenda before the 44day war failed. In the new period, the 2020 Lavrov plan is on the agenda with the mediation of Russia. Russia's policy in the South Caucasus is based on the legacy of the empire and the traditional strategies of the military order. Russian generals maintain close ties with Armenia and many of them did not prefer the continuation of the Armenia-Azerbaijan conflict as it would weaken their influence in the region (Minassian 4-6, Abelyan 22-23, Herzig 102). However, after Pavel Grachev's resignation from the post of Russian Defense Minister in 1996, the role of the Russian army began to wane. This process started to change after President Putin came to power. Instead of military diplomacy, the effect of civilian diplomacy has increased. The cooperation between Russia and Turkey on the issues like NagornoKarabakh and Syria has been facilitated with the increase in diplomacy.

Russia's view on the solution of the Nagorno-Karabakh crisis has been shaped mostly within the framework of the proposals of the Minsk Group. The Minsk group had its own plans for the solution of the Karabakh crisis. The basis for these is the return of the occupied territories to Azerbaijan gradually, the resettlement of OSCE peacekeepers and the postponed status of Nagorno-Karabakh. The idea of creating a confederation in 1998 was also discussed. This would cover Azerbaijan and Nagorno-Karabakh on equal terms (Maresca 260-265). In November-December 1997, OSCE Minsk Group co-chairs made a series of proposals for the solution of the Nagorno-Karabakh conflict. Among them, it was proposed that Azerbaijan 
would lease the Lachin corridor to the OSCE in order to connect NagornoKarabakh with the outside world. The control here would be provided by the Nagorno-Karabakh Armenians and the OSCE.

Azerbaijan rejected these proposals in accordance with national interests and international legal norms. In June 2002, Azerbaijani President Heydar Aliyev announced that the so-called proposals that were not officially announced by the participants were a proposal for the exchange of the Lachin and Meghri districts. Robert Kocharyan, president of Armenia, refused to reveal the details of these principles. In the meetings, the Armenian side took into account their statements regarding the importance of the Lachin corridor and proposed the restoration of the Aghdam-Lachin-Goris-SisyanNakhchivan route. According to the Azerbaijani side, this corridor could be the most suitable route to Nakhichevan. In this case, both Armenia and Azerbaijan would have security and free movement along the Lachin corridor.

Russia first brought up the plans of the Minsk Group for a comprehensive solution to the Karabakh conflict after the 1994 ceasefire. The basis of these plans was the deployment of the Russian army in the Nagorno-Karabakh region as a peacekeeping force. Russia organized visits to Baku, Yerevan and Khankendi in July 1994 with proposals for political solutions. Russia had a four-stage plan for the solution of the Karabakh problem. According to this plan, Russia aimed to place the Russian army in the conflict zone with the status of "UN Peacekeeping Force" and to have the solution of the problem under its control. Against this plan of Russia, especially the US, UK, Germany and Turkey did not exhibit a close attitude, and therefore Azerbaijan did not accept this plan. Western states took a decision against Russia’s plan in September 1994 involving sending peacekeepers to the region within the OSCE and making it multinational (Sarkisyan 55). According to the OSCE decision, sending a peacekeeping force of 3 thousand people to Nagorno-Karabakh would be suggested to a state to have $30 \%$ military force at most (War in the Caucasus 1994). Although Azerbaijan accepted this decision, Armenia refused it under the influence of Russia.

During Russia's influence in Ukraine, Georgia and Syria, the ceasefire between Azerbaijan and Armenia was partially broken in April 2016 and a conflict took place. This 2016 conflict has also led to an increase in Russia's 
efforts to resolve the Nagorno-Karabakh crisis. The fact that the cooperation between Turkey and Russia on Syria issue began to be threatened was among the reasons for this interest; Russia wanted the solution of the crisis of Nagorno-Karabakh and this was one of the reasons (Yilmaz, Rusyanin Suriye 10-250). Russia submitted a draft peace agreement to the parties on April 29, 2016. This draft had the character of a "Phased Solution". In this plan, the deployment of the Russian army as a peacekeeping force was especially emphasized. However, the plan could not be implemented due to the condition that the status of Nagorno-Karabakh should be determined first by Armenia (Ambrosio 95-96).

In Sochi-Astana Talks that began after the November 24, 2015 air space crisis between Turkey and Russia ended, Nagorno-Karabakh issue came into question. During the talks between Turkey and Russia in Sochi on the initiation of political peace process in Syria, a consensus was achieved on the issue that the Nagorno-Karabakh conflict should be resolved (Yilmaz, Türkiye-Rusya İlişkilerine 394, Yılmaz, Турецко-Российские 301, Yılmaz, Türkiye-Rusya İliskileri Analizi 270). A proposal called the "Lavrov Plan or the Moscow Plan" was submitted to both sides with the appointment of the Foreign Minister Lavrov by Russian President Putin. However, the Pashinyan administration was not close to the Russian plan and left the table in 2020, which disturbed Russia. Russia could not include Azerbaijan in the Eurasian Economic Union and Pakistan in the Collective Security Treaty Organization due to the veto of Armenia. In a sense, Armenia had become a problematic country for Russia. Moreover, although Pakistan was an important country for Russia, Armenia's uncompromising attitude continued. Pakistan is the only UN country that does not recognize the independence of Armenia because of Nagorno-Karabakh.

Although the "Lavrov Plan", which came to the agenda in the Sochi Talks on the Karabakh crisis, was not officially announced, it was largely covered by the ceasefire agreement articles reached on 9 November 2020. The terms added to the Lavrov Plan in 2020 are the unification of Nakhchivan with Azerbaijan by road, and that Shusha will remain under the rule of Azerbaijan. It can be said that the unconditional transfer of five of the seven regions to Azerbaijan is foreseen in the first plan. In the Lavrov Plan, the corridor would remain under Armenian control in order to secure the transition from 
Armenia to Nagorno-Karabakh. Russian peacekeepers would be brought to the region. Determination of the final status of Nagorno-Karabakh and the return of Azerbaijani refugees would be delayed. The plan that emerges today is actually a largely implementation of the Lavrov Plan.

Russia's concern about the change of its status quo that was established before in the Caucasus caused it to support Azerbaijan in the Nagorno-Karabakh crisis. The stable attitude of Turkey particularly on Nagorno-Karabakh issue has been one of the factors forcing Russia to solution. Russia thought that it would be impossible to find a solution in Karabakh by excluding Turkey. Therefore, Russia agreed on finding a solution with Turkey. This strategy can be understood from the following statement of Lavrov: "Turkey, our partner, our partnership is strategic in some of our issues. If the US entered the region (In the Caucasus), why can't Turkey enter in? If both sides agree, the Russian soldiers should be deployed in Karabakh. Libya also wants to exclude the United States, Russia and Turkey”. (Yılmaz, Rusya'nın Dağlık Karabağg). It can be understood from these words that a message was given about the Nagorno-Karabakh problem and Libya. We can say that it is the Armenia, not Russia that does not want Turkey in the table but Russia uses Armenia’s position against Turkey. Armenia's building of its national identity after independence on the hostility towards Turkey puts Russia on an advantageous ground.

Russia has a strong military and economic presence in Armenia and has a significant impact on Armenia. Russia has two military bases and many companies in Armenia. In addition, natural gas and electricity are supplied by Russia. A strong dependency relationship has been established between Russia and Armenia. Some military and political circles in Russia believed that the solution of the Nagorno-Karabakh conflict would cause Armenia to free itself from Russian influence and even accelerate its integration with the USA and NATO (Kilavuz 66, German 220).

Russia's insistence on peacekeeping in its plans can be described as a way of continuing to put pressure on both Armenia and Azerbaijan. Russia applies its foreign policy doctrine to be effective not only in Nagorno-Karabakh but also in all mediation and peacekeeping activities in the territory of the former Soviet Union. Western states avoided confrontation with Russia as much as possible in the conflicts in the territory of the former USSR. The 
purpose of establishing a three-Co-Chair countries structure within the Minsk Group was to balance the conflicting interests of Russia and the Western Minsk Group members and to minimize their doubts towards each other (Kılavuz 71, Maresca 481-482).

The Armenia-Azerbaijan conflict is positioned within the framework of Russia's geopolitical priorities and interests. Russia aimed to keep Azerbaijan and Georgia under its control with the bases it deployed in the region by preserving its political and military presence in the Caucasus until 2018 due to Armenia. Armenia was seen as a wall against Russia’s intervention from the south due to the defense and control of the Caucasus. For Russia, Biden's win in the elections in the US raised a concern that this wall would be overcome through Armenia. The stable position of Turkey as well as the elections in the USA has been effective in Russia's being active in the solution of Nagorno-Karabakh crisis. In this new situation, the possibility of Armenia to cooperate closely with the USA has been left to Russia's initiative.

\section{Conclusions}

The Nagorno-Karabakh crisis emerged as an extension of the USSR's western politics, and the USSR intervention was instrumentalized within a certain policy framework. Although Europe opened a front against the Ottoman Empire by using the Armenians in the $20^{\text {th }}$ century, in the $21^{\text {st }}$ century the European Union preferred not to be directly a party to the Karabakh issue. It also avoided competing with Russia for influence in the region. The United States of America has diplomatically stated that Karabakh is in the territorial integrity of Azerbaijan and a solution to the problem should be found. At this point, the main way to achieve lasting peace between Azerbaijan and Armenia is the land swap. Levon Ter-Petrosyan, the first president of Armenia, was removed from power when he was the president who most positively approached this formula. Although Kocharian, one of the leaders of the Karabakh clan, seems irreconcilable, he is the first president to accept the land swap. If the Armenian parliament had not been assassinated in 1999 and the prime minister had not been killed, maybe he could have signed the agreement that envisaged the land swap at the Istanbul summit. Azerbaijan has always viewed the land swap negatively. The reason for this is that the land swap in Nagorno-Karabakh will lead to people's psychological reactions to it. 
Today, the Karabakh clan sees itself very powerful and effective in politics in Armenia. According to them, it is not important that the Nakhchivan corridor is given to Azerbaijan, just like in Azerbaijan, it is important for Nagorno-Karabakh to remain in them. Because Pashinyan won the elections, the possibility of signing this peace agreement increased. If there is an agreement on land swap, Russia will definitely ask for concessions for itself. This concession can only be accepted by obtaining a military base in Nagorno-Karabakh. Turkey must strive for the initiations of the final agreement negotiations as soon as possible after determining the final borders. According to the Armenians, if Nagorno-Karabakh was given to them, an environment where they could give all kinds of land would be established. The historical and religious influence of Nagorno-Karabakh on the Armenians will cause the Meghri corridor to be transferred to Azerbaijan. The geographical location of Azerbaijan is very important in the new world order. Russia, Turkey, Iran, China and the US need the geographical position of Azerbaijan. This need is now shared between Russia and Turkey.

Russia has not supported Armenia's Nagorno-Karabakh policy since 1988; it declared its neutrality. The relationship between Azerbaijan and Russia had an effect on the Russian policy in Nagorno-Karabakh. Today, 70\% of the weapons used by the Azerbaijani army are Russian goods. Even though Azerbaijan competes with Russia in natural gas and oil, it balances this by purchasing weapons from Russia with the money it earns. Regional relations between Turkey and Russia do not have an alternative. It can be said that both countries have learned from the rivalry in the Russian Empire and the Ottoman Period. In the new period, competitions in the regions of Caucasia, Middle East, Africa etc. may have negative consequences for both countries (Yılmaz and Yakşi 9-57). Neither country intends to conflict with each other. Russia does not want to have any problems with Turkey because of Armenia since it wants to have close relations with Turkey in the future (Panossian 317, Yılmaz, Birinci Dünya 2837-2854, Yilmaz, Ermenistan Cumburiyetinde Okutulan 111-130).

There is a consensus on the development of a new policy on Turkish perception. For this, they want to start economic relations. Russia also wants to prevent the new administration in Armenia from establishing a block against Russia by placing the USA, Britain and France in the region. 
It can be said that peace and stability in the Central Asian region and the Caucasus are undesirable scenarios for some allies such as the USA and France. Russia and Turkey now agree on solving this problem or convincing the other sides to solve this problem. Nagorno-Karabakh was the beginning of the next strategic agreement between the two former empires, Turkey and Russia. Turkey and Russia agreed on Syria and Libya. They have been negotiating on the Balkans, and they want to reach an agreement on the Caucasus (Yilmaz, Rusyanın Suriye 10-250). In the new policy, it has become prominent to use Caucasus as commercially logistics strategy by providing political and economic normalization between Armenia-Azerbaijan and Armenia-Turkey. The South Caucasus (Georgia, Azerbaijan and Armenia) is of great importance to Russia for a number of reasons. Firstly, it is located at the exit of Central Asia and China to the West, and there are energy routes and trade routes that bypass Russia. Russia also thinks that the peace environment between Azerbaijan and Nagorno-Karabakh in the region may prevent Georgia from joining NATO (Yılmaz, Putin Dönemi 20-334).

Although Russia’s political attitude is generally shaped within the framework of the territorial integrity of Azerbaijan, it has been achieved to return to the peace table with the liberation of other Azerbaijani territories from the occupation except Nagorno-Karabakh. Russia has a plan to guarantee the rights of Armenians in Nagorno-Karabakh. However, since the Pashinyan administration's insistence on self-determination threatened Russia, it ignored this. The fact that the Pashinyan administration has accepted self-determination in Nagorno-Karabakh or Russia's mediator role in this process is a source of concern for Russia, which is governed as a federation, since this situation may set an example for ethnic peoples living in Russia and they may claim the same rights in the lands of Russia in the future (Yilmaz, Rusya'da Kimler 20-468). Russia considers that everyone will benefit from the return of Nagorno-Karabakh to Azerbaijan, depending on the latest developments in Armenia. In this way, it will be contributed to the developments of the regions due to the open borders between Iran, China, Turkey and Russia as well as preventing the settlement of the US, England and Israel in the region. Both Russia and Turkey think that the conflict that has continued between Azerbaijan and Armenia for 100 years can be resolved by land swap. 
The land swap formula between Azerbaijan and Armenia provides important gains for both countries. In this way, the competition that has been going on for a century will come to an end, and Armenia will be economically connected to Asia and Europe without interruption. The opening of the Meghri corridor or the land swap will also contribute to the normalization of Turkey-Armenia relations. An equitable land swap should be considered in order to turn the historical rivalry between Russia-Turkey and AzerbaijanArmenia into cooperation. Since the foreign-dependent policy that came to power in Armenia using the Nagorno-Karabakh crisis as an excuse will focus on the development of the country again, it may cause cooperation among the countries of the region to solve many problems. With China's activation of the Silk Road Project, Russia's direct road and rail connection to Europe may cause an economic and political development in the region.

\section{References}

Abdullayev, Elşad. Dağlık Karabă̆ Problemi Beynelhalk Hukuk Müstevisinde. Teshil Neşriyat1, 2004.

Abelyan, Armen V. Russia's National Interests in the Transcaucasus and the U.S. Policy: Implications for Armenian National Security. Thesis. Naval Postgraduate School, 2006.

Abilov, Shamkhal. "The Discourse "One Nation Two State: The Position of Turkey in the Nagorno-Karabakh Conflict." Journal of Caspian Affairs, vol. 1, no. 2, 2005, pp. 29-58.

Akçay, Deniz. "Dağlık Karabağ Uyuşmazlığında Self-Determinasyon Tezlerinin Göreceliği." Ermeni Araştırmaları, no. 65, 2020, pp. 101-129.

Aktaş, Hayati. Dağglık Karabăg Sorunu. Türk Dünyası Araştırmaları Vakfı Yayınları, 2001.

Ambrosio, Thomas. "Unfreezing the Nagorno-Karabakh Conflict? Evaluating Peacemaking Efforts under the Obama Administration." Ethnopolitics, vol. 10, no. 1, 2011, pp. 93-114.

ANI. "Turgut Ozal to President Bush: Armenia and Azerbaijan could swap territory [KarabakhandMeghri].”31 Jenuary2019.http://www.aniarc.am/2019/01/31/ turgut-ozal-to-president-bush-armenia-and-azerbaijan-could-swapterritory-karabakh-and-meghri/?fbclid=IwAR2MJE6Avt_oEabioibaIa-2_ Gp65JeDs0Gk-68k5sTDqz2oR9XLAnaniok (Accessed:13.12.2020).

Aras, O. et al. Karabă̆ Savaşı, Siyasi Hukuki-Ekonomik Analiz. Kafkasya Araştırmaları Enstitüsü, 2008. 
"Armenia and Azerbaijan: Key West Peace Talks. Briefing by Three Co-Chairs on Key West Peace Talks". Archive of U.S. Department of State, Key West, Florida, 6 April 2001. https://2001-2009.state.gov/p/eur/rls/rm/2001/2098. htm [Accessed: 14.12.2020].

Azerbaycan Gazetesi. 23 Temmuz 1997.

Azarbaycan Tarixi. C. VI. Elm. 2007.

Baguiyov, Adil. "Nagorno-Karabakh:Basis and Reality of Soviet Era Legal and Economic Claims Used to Justify the Armenia-Azerbaijan War." Caucasian Review of International Affairs, vol. 2, no. 1, 2008, pp. 11-24.

Baker, Mark, and Emil Danielyen. "Armenia: US Diplomat Tries to Close Karabakh Deal.” Radio Free Europe, 9 October 1999. https://www.rferl. org/a/1092506.html [Accessed: 14.12.2020].

Başer, B., and A. Swain. "Diaspora Design Versus Homeland Realities: Case Study Of Armenian Diaspora." Caucasian Review of International Affairs, vol. 3, no. 1, 2009, pp. 45-62.

Caferov, Nazim, and Araz Aslanlı. "Karabağ Sorununda Ateşkes ve Rusya.” Ermeni Araştırmaları, no. 53, 2016, pp. 239-260.

Cheterian, Vicken. War and Peace in the Caucasus; Ethnic Conflict and the New Geopolitics. Colombia University Press, 2009.

Chorbajan, Levon et al. The Caucasian Knot:The History and Geopolities of Nagorno Karabagh. Zed Books, 1995.

Coyle, James C. Russia's Interventions in Ethnic Conflicts, The Case of Armenia and Azerbaijan. Palgrave Macmillan, 2020.

De Waal, Thomas. Black Garden: Armenia and Azerbaijan through Peace and War. New York University Prese, 2004.

De Waal, Thomas. Черный сад. Армения и Азербайджан между миром и войной. РОССПЭН, 2014.

German, Tracey. "The Nagorno-Karabakh Conflict between Azerbaijan and Armenia: Security Issues in the Caucasus." Journal of Muslim Minority Affairs, vol. 32, no. 2, 2012, pp. 216-229.

Harutunian, Ruben. "The Nagorno-Karabakh Conflict: Moving from Power Brokerage to Relationship Restructuring." International Negotiations, vol. 15, no. 1, 2010, pp. 57-80.

Hasanov, Ali. Azerbaycan ve AGİK. Ermenistan-Azerbaycan Çatışması ve Dă̆lık Karabăg Problemi Umumi Avrupa Tehlükesizliyi Fonunda. 1997.

Herzig, Edmund. The New Caucasus, Armenia, Azerbaijan and Georgia. The Royal Institute of International Affairs, 1999.

Hesenov, Ali. Azerbaycan ve AGİT. 1997.

Hesenov, Ali. Azerbaycan'ın Xarici Siyaseti: Avrupa Ülkeleri ve ABD. 1998. 
Hopmann, P. Terrence. "Minsk Group Mediation of the Nagorno-Karabakh Conflict: Power, Interest and Identity." Paper prepared for presentation at the Annual Meeting of the American Political Science Association. August 29-1 September 2013, pp. 10-11.

"How the "Goble Plan" was born and how it remains a political factor". 9 July 2000.

https://reliefweb.int/report/armenia/how-goble-plan-was-born-and-how-itremains-political-factor [Accessed:14.12.2020].

Huseynov, Tabib. "Mountainous Karabakh: New Paradigms for Peace and Development in the 21st Century." International Negotiation, vol. 15, no. 1, 2010, pp. 7-31.

Imranli-Lowe, Kamala. "The Paris Peace Conference and the Armenian Arguments on Garabagh.” Central Asian Survey, vol. 34, no. 2, 2015, pp. 219-236.

Ismailzade, Fariz. "The Nagorno-Karabakh Conflict: Current Trends and Future Scenarios." Instituto Affari Internazionali (IAI), Working Papers, vol. 11, no. 29, 2011, pp. 1-10.

İbrahimova, Gülzar, and Vagif Valizada. "Sovietization Of Azerbaijan And Invasion Plans of Nakhchıvan Armenians". The Journal of International Civilization Studies/Uluslararası Medeniyet Çalışmaları Dergisi, vol. IV, no. I, 2019, pp. 28-84.

İsmayıl, Mahmud. Azerbaycan Taribi. Azerneşr, 1993.

İsmayılov, Füzuli. Karabağ Konflikti ABD’nin Global Siyaseti Konteksinde. Azerbaycan Milli Ansklopedi Neşriyat1, 2001.

İşyar, Ömer Göksel. Bölgesel ve Global Güvenlik Çıkarları Bağlamında Sovyet-Rus Dış Politikaları ve Karabă̆ Sorunu. Alfa Yayınları, 2004.

Jacoby, Volker. "The Role of the OSCE: An Assessment of International Mediation Efforts." The Limits of Leadership: Elites and Societies in the Nagorny Karabakh Peace Process, Conciliation Resources. Der. Laurance Broers, 2005, pp. 30-33. Kelbizadeh, Elnur. "Robert Koçaryan’ın Cumhurbaşkanlığı Döneminde Ermenistan-İran İlişkileri.” Ermeni Araştırmaları, no. 62, 2019, pp. 73-94.

Kerimov, Bahadur. Haydar Aliyev Döneminde Azerbaycan’ın Dış Politikası (1993 2003). Yüksek Lisans Tezi. İstanbul Üniversitesi, 2007.

Kılavuz, İdil Tunçer. "Dağlık Karabağ Müzakerelerinin Geleceği”. TİKA Avrasya Etüdleri, vol. 52, no. 2, 2017, pp. 51-78.

Kouhi-Esfahani, Marzieh. Iran's Foreign Policy in the South Caucasus: Relations with Azerbaijan and Armenia. Routledge, 2019.

Laitin, David D., and Ronald Grigor Suny. "Armenia and Azerbaijan: Thinking a Way out of Karabakh". Middle East Policy, vol. VII, no. 1, 1999, pp. 145176. 
Leckie, Chanda Allan. The Nagorno - Karabakh Conflict: Obstacles and Opportunities for a Settlement. M.A. Thesis. Polytechnic Institute and State University, 2005.

Lütem, Ömer E. "Facts and Comments". Ermeni Arastırmaları/Armenian Studies, no. 2, 2001, pp. 9-29.

Lütem, Ömer Engin. “Türkiye-Ermenistan İlişkilerinin Güncel Durumu.” Ermeni Araştırmaları, no. 50, 2015, pp. 231-373.

“Madrid Ministerial Council Document." OSCE, 29-30 November 2007. https:// www.osce.org/mc/36562 [Accessed:14.12.2020].

Makili-Aliyev, Kamal. "Nagorno-Nagorno-Karabakh Conflict in International Legal Documents and International Law." Center for Strategic Studies under the President of the Republic of Azerbaijan, Fall 2013, pp. 76-82.

Maresca, John. "Lost Opportunities in Negotiating the Conflict over NagornoKarabakh.” International Negotiation, vol. 1, no. 3, 1996, pp. 471-499.

Maresca, John J. "Resolving the Conflict over Nagorno-Karabakh Lost Opportunities for International Conflict Resolution.” Chester A. Crocker and Fen Osler Hampson with Pamela Aall (eds). Managing Global Chaos Sources of and Responses to International Conflict, United States Institute of Peace Press, 1997, pp.139-175.

Mehdiyev, Ramiz. Azerbaycan, Küreselleşmenin Talepleri. DA Yayıncılık, 2005.

Mehtiyev, Ramiz. Lizbon Sammiti-96. 1997.

Mehtiyev, Elkhan. "Armenia-Azerbaijan Prague Process: Road Map to Peace or Stalemate for Uncertainty?" Conflict Studies Research Centre Caucasus Series, vol. 5, no. 23, 2005, pp. 1-20.

Mehmetov, İsmail. Türk Kafkasinda Siyasi ve Etnik Yapı: Eski Çağlardan Günümüze Azerbaycan Tarihi. Çev. Ekber Necef and Şamil Necefov. Ötüken Yayınları, 2009.

Mehmediyev, R. Dă̆lık Karabă̆ Kaynaklarm Diliyle Tarih. Berikan Yayınları, 2015. Mehmedova, H. Hankendiden Başlayan İsgal, Karabă̆ Dün Bugün ve Sabah. Karabağ Azatlık Teşkilatı, 2014.

Minassian, Gaidz. "Armenia, A Russian Outpost in the Caucasus?" Russial NIS Center. February 2008. http://www.ifri.org/?page=contributiondetail\&id=4943\&id_provenance=97 [Accessed:14.12.2020].

Mufson, Steven. "Leader Had Just Met with State's Talbott." The Washington Post, 28 October 1999. https://www.washingtonpost.com/wp-srv/WPcap/199910/28/084r-102899-idx.html [Accessed: 14.12.2020].

Musayev, Tofik. Provovie Aspektı Nagorno-Karabaxskogo Konflikta. 2001.

Mustafayev, N. The Impact Of Nagorno-Karabakh Confilict On Ekonomic Cooperation In The South Caucasus. Gündoğan Yayınları, 2015. 
“Nagorno-Karabakh: New Openning or More Peril?" International Crisis Group, no. 239, 2016, pp. IV+22.

Neciyev, E. “Azerbaycan'ın Sovyetleştirilmesi Sürecinde Karabağ Problemi.” Ermeni Araștırmaları Dergisi, no. 39, 2011, pp. 163-186.

“OSCE Minsk Group Co-Chairs Issue Statement on Nagorno-Karabakh.” Press Release. 29 November 2007. http://www.osce.org/mg/49237 [Accessed: 14.12.2020]

“OSCE Minsk Group Co-Chairs Issue Statement on Nagorno-Karabakh.” Press Release, 19 March 2008 http://www.osce.org/mg/49570 [Accessed: 14.12.2020]

Özkök, Ertuğrul. "Beş Yerden Çekilsinler Kapıyı Hemen Açalım.” Hürriyet: Interview with Ilham Aliyev, 9 April 2004.

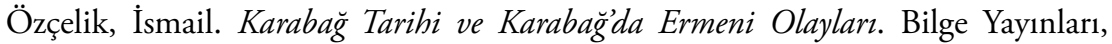
2003.

Özkul, Osman. Dă̆lık Karabă̆ Problemi. Gündoğan Yayınları, 2014.

Panossian, Razmik. The Armenians: From Kings and Priests to Merchants and Commissars. Columbia University Press, 2006.

Papazian, Talin. "From Ter-Petrossian to Kocharian: Explaining Continuity in Armenian Foreign Policy 1991-2003.” Demokratizatsiya, vol. 14, no. 2, 2006, pp. 235-251.

Pokalova, Elena. "Conflict Resolution in Frozen Conflicts: Timing in Nagorno Karabakh." Journal of Balkan and Near Eastern Studies, vol. 17, no. 1, 2015, pp. 68-85.

RIAFAN. "Пригожин считает, что игры Пашиняна с США привели к войне в Карабахе.” 30 September 2020, https://riafan.ru/amp/1316789prigozhin-schitaet-chto-igry-ssha-s-pashinyanom-priveli-k-voine-vkarabakhe?_twitter_impression=true [Accessed: 13.12.2020].

RUSEN. “Özal'ın Karabağ Değişim Planı”. (14 November 2020). http://www. rusen.org/ozalin-karabag-degisim-plani/ [Accessed:15.12.2020].

Sarıahmetoğlu, N. Karabă̆. IQ Yayınları, 2011.

Sarkisyan, Manvel. Politiçeskiye Problemi Kavkaza: Armeniya, Politika Armenii $v$ Regione. The Armenian Center for National and İnternational Studies, 1998.

"Strobe Talbott Returns to Armenia Meets Koçaryan”. Asbarez, 29 October 1999. http://asbarez.com/41457/strobe-talbott-returns-to-armeniameetsKoçaryan/ [Accessed:14.12.2020].

Swietochowski, T. Russia and Azerbaijan: A Borderland in Transition. Columbia University Press, 1995.

Şavrov, N.N. Novaya Ugroza Russkomu Delu v Zakavkazie. Sankt Petersburg, 1991. 
Şıhaliyev, Emin. "Ermenilerin Nahçıvan İddiaları ve XX. Yüzyıl Başlarında Yapılan Katliamlarda Büyük Güçlerin Rolü”. Ermeni Araştırmaları, no. 53, 2016, pp. 175-192.

Taşkıran, Cemalettin. Geçmişten Günümüze Karabăg Meselesi. Genel Kurmay Basımevi, 1995.

Tohidi, Solmaz Rüstemova. "Birinci Dünya Savaşı Yıllarında Ermeniler Tarafından Azerbaycan'ın Erivan, Zengezur ve Karabağ Eyaletlerinde Müslüman Nüfusunun Soykırımı." Yeni Türkiye, Ermeni Meselesi Özel Sayısı, no. 63, 2014, pp. 2653-2666.

Vahapzade, Bahtiyar. Şenbe Gecesine Giden Yol. Azerneşr, 1991.

"Vsesoyuznaya perepis naseleniya ot 1926 g." Zakavkazskaya SFSR, no. XIV, 1929, pp.11-13.

"War in the Caucasus: A Proposal for Settlement of the Conflict over NagornoKarabakh." Special Report of the United States Institute of Peace. Washington DC, 1994. http://www.usip.org/sites/default/files/SR9.pdf [Accessed:14.12.2020].

Yılmaz, Salih. "Ermenistan Cumhuriyeti'nde Okutulan 10. Sinıf Tarih Ders Kitabında Türkler Aleyhine İfadeler ve Sözde Ermeni Soykırımı.” Türk Dünyası Araştırmaları, no 177, 2008, pp. 111-130.

Yılmaz, Salih. "Birinci Dünya Savaşı'nın 100. Yılında Ermeni Sorunu, Tehcir ve Pontus Sorununa Genel Bakış.” Yeni Türkiye, no. 63, 2014, pp. 2837-2854. Yılmaz, Salih, and Abdullah Yakşi. "Osmanlı Devleti'nden Günümüze Türk-Rus İlişkileri.” TYB Akademi, no. 17, 2016, pp. 9-57.

Yılmaz, Salih. Türkiye-Rusya İlişkilerine Bakış (2016-2017). Nobel Yayınları, 2018.

Yılmaz, Salih. Putin Dönemi Rusya Dış Politikası ve Güvenlik Doktrinleri. Nobel Yayınları, 2019.

Yılmaz, Salih. 2018 Yilında Türkiye-Rusya İlişkilerinde Neler Oldu? Что случилось в турецко-российских отношениях в 2018 Году?. Nobel Yayınları, 2019.

Yılmaz, Salih. “Rusya’nın Dağlık Karabağ için çözüm planı ne?”. Fikir Turu, 2020. https://fikirturu.com/jeo-strateji/rusyanin-daglik-karabag-icin-cozumplani-ne/ [Accessed: 13.12.2020].

Yılmaz, Salih. "Ermenistan-Azerbaycan Barış Anlaşmasının Değerlendirilmesi." Karabăg Zaferi: Kafkasya'da Yeni Dengelerden Türk ve İlam Dünyasında Yeni İsbirliği Modeline, Rapor, Ankara Yıldırım Beyazıt Üniversitesi: ULİSA, 2020, pp. 34-39.

Yılmaz, Salih. Rusya'nın Suriye Politikası. İlbilge Yayınları, 2020.

Yılmaz, Salih. Putin Era Russia's Foreign Policy and Security Doctrines, Nobel Yayınlar1, 2020. 
Yılmaz, Salih. Rusya'da Kimler Yassıyor?, Rusya Federasyonu Etnik Atlası. Rusya Federasyonu Büyükelçiliği-Kültür Bakanlığı-Ankara Rusya Araştırmaları Enstitüsü (RUSEN), 2020.

Yılmaz, Salih. Туреико-Российские Отношения-2019. İlbilge Yayınları, 2020.

Yılmaz, Salih. Türkiye-Rusya İlişkileri Analizi-2019. İlbilge Yayınları, 2020.

Ziyadov, Taleh. "Nagorno-Karabakh Negotiations: Through the Prism of a MultiIssue Bargaining Model." International Negotiation, vol. 15, no. 1, 2010, pp. 107-131. 


\section{Dağlık Karabağ Krizi Çözümünde Arazi Takası Formülü: Goble Planı ve Lavrov Planı}

\section{Salih Yılmaz ${ }^{* *}$}

Öz

Dağlık Karabağ tarihini incelediğimizde, Ermeni ve Azerbaycan tarihçilerin bin yıllık tarihin gerçeğini aradıklarını ve bu da tartışmalı bir konu oluşturduğunu görüyoruz. Dağlık Karabağ Özerk Bölgesi, 1923 yilında kurulmuş ve Azerbaycan'da resmi statüye sahip olmuştur. Bu ihtilafı çözmek için SSCB'nin dağılmasının ardından AGİT Minsk Grubu çatısı altında çözüm önerileri sunuldu. Bu çalışmada Dağlık Karabağ krizinin çözümüne dair arazi takasına dayalı planlar ve uluslararası çözüm önerileri karşılaştırmalı olarak ele alınmaktadır. Ayrıca 9 Kasım 2020 tarihinde imzalanan anlaşma çerçevesinde uygulanacak ve ileride tartışma konusu olacak arazi takas stratejisi de bu çalışmada değerlendirilecektir.

\section{Anahtar Kelimeler}

Dağlık Karabağ, Minsk Grubu, Azerbaycan, Ermenistan, Goble Planı, Lavrov Planı, Lizbon Deklarasyonu, Madrid İlkeleri.

\footnotetext{
Geliş Tarihi: 21 Aralık 2020 - Kabul Tarihi: 30 Kasım 2021

Bu makaleyi şu şekilde kaynak gösterebilirsiniz:

Yilmaz, Salih. "Land Swap Formula in the Nagorno-Karabakh Crisis Solution: Goble Plan and Lavrov Plan.” bilig, no. 100, 2022, ss. 177-209.

"* Prof. Dr., Ankara Yıldırım Beyazıt Üniversitesi, İTBF, Tarih Bölümü - Ankara / Türkiye

ORCID: 0000-0002-5413-0703

salihyilmaz76@gmail.com
} 


\title{
Формула обмена землей в
}

\section{урегулировании кризиса в Нагорном Карабахе: план Гобла и план Лаврова*}

\section{Салих Йылмаз}

\begin{abstract}
Аннотация
Когда мы исследуем историю Нагорного Карабаха, мы видим, что армянские и азербайджанские историки искали истину в тысячелетней истории, которая, в свою очередь, порождает спорный вопрос. Нагорно-Карабахская автономная область была образована в 1923 году и имела официальный статус в составе Азербайджана. Предложения по разрешению этого конфликта после распада СССР были представлены под эгидой Минской группы ОБСЕ. В данном исследовании сравниваются предложения по международным решениям и планы, основанные на обмене территориями. Кроме того, в исследовании будет проведена оценка стратегии обмена землями, которая будет реализована в рамках соглашения о прекращении огня, подписанного 9 ноября 2020 года, и станет темой для обсуждения в будущем.

\section{Ключевые слова}

Нагорный Карабах, Минская группа, Азербайджан, Армения, план Гобла, план Лаврова, Лиссабонская декларация, Мадридские принципы.
\end{abstract}

Поступило в редакцию: 21 декабря 2020 г. - Принято в номер: 30 ноября 2021 г. Ссылка на статью:

Yllmaz, Salih. "Land Swap Formula in the Nagorno-Karabakh Crisis Solution: Goble Plan and Lavrov Plan." bilig, no. 100, 2022, pp. 177-209.

** Проф., д-р. Университет Йылдырыма Беязита, Анкара, факультет гуманитарных и социальных наук, исторический факультет - Анкара / Турция ORCID: 0000-0002-5413-0703

salihyilmaz76@gmail.com 
